\title{
Properties of dark chocolate enriched with free and encapsulated chlorogenic acids extracted from green coffee
}

\section{Propriedades de chocolate amargo enriquecido com ácidos clorogênicos livres e encapsulados extraído do café verde}

Didar Zohreh* (1)

\footnotetext{
${ }^{1}$ Department of Food Science and Technology, Neyshabur Branch, Islamic Azad University, Neyshabur, Iran
}

${ }^{*}$ Corresponding Author: Didar Zohreh, Department of Food Science and Technology, Neyshabur Branch, Islamic Azad University, Neyshabur, Iran, e-mail: z_didar57@yahoo.com

Cite as: Didar, Z. (2020). Properties of dark chocolate enriched with free and encapsulated chlorogenic acids extracted from green coffee. Brazilian Journal of Food Technology, 23, e2019118. https://doi.org/10.1590/19816723.11819

\begin{abstract}
To increase the functionality of dark chocolate, chlorogenic acids extracted from green coffee were added in free or encapsulated forms at different concentration $(10,20,30,40$ and $50 \mathrm{mg} / 5 \mathrm{~kg}$ of free chlorogenic acids and equal quantity of encapsulated form). The extraction of chlorogenic acids was carried out by maceration of ground green coffee beans in distilled water $\left(30 \mathrm{~min}\right.$ at $\left.80^{\circ} \mathrm{C}\right)$, then, cooling, filtration and adsorption by active carbon were done. The final step was filtration and desorption from active carbon and rotary drying (at $60{ }^{\circ} \mathrm{C}$ and $120 \mathrm{rpm}$ ). Encapsulation of chlorogenic acids was done by coacervation of pectin and gelatin. For quality assessment, several analysis on chocolate samples were performed included color index and melting behavior by Differential Scanning Calorimeter. Flow behavior of the chocolate samples melted at $40^{\circ} \mathrm{C}$ was determined using stress or strain controlled rheometer. The microstructure of the chocolate samples was analyzed by Scanning Electron Microscope technique at 500-1000x magnification. Particle size distribution and sensory evaluation was also performed. Results showed addition of free and encapsulated forms of chlorogenic acids decreased $T_{\text {onset, }} T_{\text {peak }}$ and $\Delta H$ of dark chocolate. Casson viscosity increased in the case of addition chlorogenic acids. Color indexes of chocolate samples were influenced by addition of chlorogenic acids. Particle size distribution decreased with addition of free form and increased when encapsulated form was added. Sensory characteristics were also influenced by chocolate formulation and samples included encapsulated chlorogenic acids exhibit better sensory properties than samples enriched with free form.
\end{abstract}

Keywords: Coacervation; Encapsulation; Melting behavior; Casson viscosity.

\section{Resumo}

Para aumentar a funcionalidade do chocolate amargo, os ácidos clorogênicos extraídos do grão de café verde foram adicionados ao produto na forma livre ou encapsulada, em diferentes concentrações (10, 20, 30, 40 e $50 \mathrm{mg} / 5 \mathrm{~kg}$ de ácidos clorogênicos livres e quantidade igual de forma encapsulada). A extração de ácidos clorogênicos foi realizada por maceração de grãos de café verde em água destilada $\left(30 \mathrm{~min}\right.$ a $\left.80^{\circ} \mathrm{C}\right)$; em seguida, foram realizados resfriamento, filtração e adsorção por carvão ativo. $O$ passo final foi filtração e dessorção por meio de carvão ativo 
e secagem rotativa (a $60^{\circ} \mathrm{C}$ e $120 \mathrm{rpm}$ ). O encapsulamento de ácidos clorogênicos foi realizado por coacervação de pectina e gelatina. Para avaliação da qualidade, foram realizadas diversas análises em amostras de chocolate, incluindo índice de cor, comportamento na fusão por calorimetria de varredura diferencial e comportamento de fluxo das amostras de chocolate derretido a $40{ }^{\circ} \mathrm{C}$, utilizando reômetro controlado por tensão ou deformação. A microestrutura das amostras de chocolate foi analisada por microscopia eletrônica de varredura, com ampliação de 500-1000 vezes. Distribuição de tamanho de partícula e avaliação sensorial também foram realizadas. Os resultados mostraram que a adição de ácidos clorogênicos na forma livre e encapsulada diminuiu $T_{\text {onset, }} T_{\text {peak }} e$ $\Delta \mathrm{H}$ de chocolate amargo. A viscosidade de Casson aumentou com a adição de ácidos clorogênicos. Índices de cor das amostras de chocolate foram influenciados pela adição de ácidos clorogênicos. A distribuição do tamanho das partículas diminuiu com a adição da forma livre de ácidos clorogênicos e aumentou no caso da forma encapsulada. As características sensoriais também foram influenciadas pela formulação do chocolate e as amostras adicionadas de ácidos clorogênicos encapsulados exibiram melhores propriedades sensoriais do que as amostras enriquecidas com a forma livre.

Palavras-chave: Coacervação; Encapsulamento; Comportamento na fusão; Viscosidade de Casson.

\section{Introduction}

Nowadays, natural antioxidants draw attention as food preservatives and preventing oxidation of foods. Furthermore, antioxidants have several health benefits such as anti- cancer activity, prevention of cardiovascular and neurological diseases and anti-inflammatory, antibacterial, anti-allergic, anti-hypertensive, antiviral and skin wound healing effects (Ozkan et al., 2019). Different food antioxidants have been classified into two main groups based on their chemical structure and functions: water soluble and lipid soluble bioactive compounds. Citrates, norbixin, betalains, most of the phenolics, flavanoids and anthocyanins are water soluble and carotenoids, tocopherols, terpenoids and vitamin $\mathrm{E}$ are lipid soluble bioactive components (Carocho et al., 2018). Chlorogenic acids (CGA) are a common name of different components composed of mono- and di-acyl quinic acids, with caffeic, ferulic, and p-coumaric acids as the main acylating residues. Chlorogenic acids are found widespread in plant materials and its antioxidant properties were reported (Yashin et al., 2013).

Several factors have adverse effect on antioxidant activity (light, oxygen, temperature, moisture and presence of unsaturated bonds in the molecular structures) which cause antioxidant degradation. Microencapsulation with a suitable carrier is an alternative method for enhancing the storage and environmental stability of bioactives. This method also masks flavor, bitter taste and astringency of polyphenols (Ballesteros et al., 2017). For efficient microencapsulation, the selection of suitable wall materials with the minimum adverse effect of different food properties is necessary. Complex coacervation is an approach that uses a combination of encapsulating substances. In this method, electrostatic attraction is provided between a minimum of two oppositely charged macromolecules. Although other weak interactions such as hydrogen bonding and hydrophobic interactions also may contribute to the complex formation (Jain et al., 2016), this method is commonly used for encapsulating materials with lipophilic nature such as palm oil (Rutz et al., 2017), Cinnamaldehyde (Muhoza et al., 2019).

Gelatin and pectin are two of the most biodegradable biopolymers commonly used in food and pharmaceutical industry (Wu \& McClements, 2015). Gelatin and pectin coacervate are mainly prepared through electrostatic attraction between the positive charge on protein surface and negatively charged pectin carboxylic group (Xu et al., 2017). Their application for encapsulation were studied by some researchers (Muhoza et al., 2019).

Chocolate is the one of most popular foods around the world. They are divided into three main classes (dark, milk and white) according to their formulation (the content of cocoa solid, milk fat and cocoa butter) (Afoakwa, 2010, p. 275). Dark chocolate is a rich source of flavonoids with high antioxidant activity and 
beneficial health effects such as free radical scavenging (Silva Medeiros et al., 2015), increased insulin sensitivity (Ramos et al., 2017). Some attempts to enhance functional activity of dark chocolate were done such as adding probiotic bacteria (Kemsawasd et al., 2016), eicosapentaenoic and docosahexaenoic acids (Toker et al., 2018).

This study was focused on assessing the effects of chlorogenic acids addition in different forms (free or encapsulated) into dark chocolate formulation and examining the quality characteristics of dark chocolates such as physical, physico-chemical, thermo-gravimetric, rheological, textural and sensory properties.

\section{Material and methods}

\subsection{Materials}

For preparing dark chocolate, specific amounts of the following materials were used. $43.81 \mathrm{~g}$ sugar, $44.91 \mathrm{~g}$ Cocoa, $10.78 \mathrm{~g}$ Cocoa butter, $0.52 \mathrm{~g}$ Soy lecithin (Son et al., 2018). Free and encapsulated chlorogenic acids were also added at the ratio of $10,20,30,40$ and $50 \mathrm{mg} / 5 \mathrm{~kg}$. Considering the encapsulation efficiency equal to $99.71 \%$ and for equal addition of chlorogenic acids to chocolate formulation, the microcapsules of chlorogenic acids added to chocolate formulation were 10.02, 20.05, 30.08, 40.11 and $50.14 \mathrm{mg} / 5 \mathrm{~kg}$ ). All chemicals used in this study were purchased from Merck.

\subsection{Extraction of chlorogenic acids}

Extraction of chlorogenic acids was carried out according to method demonstrated by Suarez-Quiroz et al. (2014). $100 \mathrm{~g}$ of green coffee powder was mixed with $500 \mathrm{~mL}$ distilled water, stirred for $30 \mathrm{~min}$ at $80{ }^{\circ} \mathrm{C}$ (in the dark condition). Thereafter, the mixture was cooled, and vacuum filtered through celite $(1 \mathrm{~cm})$. The $\mathrm{pH}$ of aqueous extract obtained from extraction step was adjusted to $\mathrm{pH} 3.0$ with phosphoric acid. Active carbon $(40 \mathrm{~g} / \mathrm{L})$ was added and magnetically stirred for $30 \mathrm{~min}$ at $60^{\circ} \mathrm{C}$, under dark condition. After cooling to ambient temperature, the mixture was vacuum filtered through celite $(1 \mathrm{~cm})$. Chlorogenic acids were desorbed from active carbon using ethanol $96 \%(\mathrm{v} / \mathrm{v})$, and dried with a rotary evaporator at $60{ }^{\circ} \mathrm{C}$ and $120 \mathrm{rpm}$.

\subsection{Encapsulation of chlorogenic acids}

Pectin and gelatin were dissolved in deionized water at $60{ }^{\circ} \mathrm{C}$ for $2 \mathrm{~h}$. For removing air bubbles, the biopolymer solutions were centrifuged at $5000 \mathrm{rpm}$ for $30 \mathrm{~min}$ at room temperature.

The stock solution of gelatin/ pectin with ratio of $3: 1$ was prepared. The mixture was held at $45{ }^{\circ} \mathrm{C}$ for 30 min under a stirring rate of $300 \mathrm{rpm}$. Acetic acid $(10 \% \mathrm{v} / \mathrm{v})$ was used to adjust the $\mathrm{pH}$ at the coacervation optimum $\mathrm{pH}$ (equal to 3.8). Then, an ice-water bath was used to quickly decrease the temperature below $15{ }^{\circ} \mathrm{C}$ for $30 \mathrm{~min}$ at $300 \mathrm{rpm}$ to induce complete formation of coacervates and enhance the number of intra molecular or intermolecular binding and formation of a gel network structure (Muhoza et al., 2019). The obtained coacervated microcapsules was stored at $6{ }^{\circ} \mathrm{C}$ for $24 \mathrm{~h}$. The resulted coacervated microcapsules were freeze dried into powder.

\subsection{Encapsulation efficiency}

For encapsulation efficiency assessment, the chlorogenic acids content before and after encapsulation was measured according to spectrophotometric method outlined by Belay \& Gholap (2009) at the wavelength region of 200 to $500 \mathrm{~nm}$, (distilled water was used as blank) by Beer-Lambert's Law at $\lambda$ max $=324 \mathrm{~nm}$ by spectrophotometer (Jenway6305, UK). Extraction of chlorogenic acids from capsules were performed according to Cheraghali et al. (2016). $200 \mathrm{mg}$ of microcapsule were dissolved in extraction solution 
(methanol: acetic acid, distilled water in the ratio of 50:8:42), stirred for $1 \mathrm{~min}$. Thereafter, sonication was performed for $20 \mathrm{~min}$ (Eurosonic 4D). Centrifugation at $5000 \mathrm{rpm}$ for $10 \mathrm{~min}$ (ALC4232, Germany) was carried out. The collected supernant was used for chlorogenic acids content determination. Encapsulation efficiency was calculated as the Equation 1 below.

$\%$ Encapsulation efficiency $=\frac{\text { Content of chlorogenic acids extracted from microcapsules }}{\text { Chlorogenic acids content } u \text { used }} \times \mathbf{1 0 0}$

\subsection{Fourier-transform Infrared Spectroscopy (FTIR)}

Fourier-transform infrared spectroscopy is an approach for the analysis of materials structure and for the assessment of functional groups present in materials.

The Fourier-transform infrared spectroscopy (FTIR) spectra analysis was performed before and after the encapsulation process. This analysis was carried out by a Perkin-Elmer FTIR spectrophotometer (model Spectroma2) in the range of 4000 to $500 \mathrm{~cm}^{-1}$.

\subsection{Scanning Electron Microscope (SEM)}

Morphological observation was performed by scanning electron microscope (phenom proX) at $20 \mathrm{kV}$ with magnification of 3000 and 5000 for microcapsules and magnification of 500-3000 for chocolate texture.

\subsection{Dark chocolate preparation}

For dark chocolate preparation, $43.81 \mathrm{~g}$ sugar, $44.91 \mathrm{~g}$ cocoa, $10.78 \mathrm{~g}$ cocoa butter, $0.52 \mathrm{~g}$ soy lecithin were the original chocolate formulation ingredients (Son et al., 2018).

All ingredients were poured in a laboratory ball mill (Arman Co, Iran) and mixing, milling and crunching steps were simultaneously done at $60^{\circ} \mathrm{C}, 100 \mathrm{rpm}$ and $90 \mathrm{~min}$ (Kiomarsi et al., 2017).

After crunching, chlorogenic acids were mixed to the chocolate mass at $35^{\circ} \mathrm{C}$ (according to Table1). Thereafter, the mass was mixed about $5 \mathrm{~min}$. Addition of chlorogenic acids was followed by a tempering three-stages process $\left(33\right.$ to $35^{\circ} \mathrm{C}, 24$ to $25^{\circ} \mathrm{C}$ and 25 to $26^{\circ} \mathrm{C}$ ). Subsequent stages included the molding in $2 \times 2 \times 0.5 \mathrm{~cm}$ plastic containers and vibration steps was carried out at 27 to $30^{\circ} \mathrm{C}$ and cooling at $5{ }^{\circ} \mathrm{C}$. Samples were kept at 13 to $15^{\circ} \mathrm{C}$ prior to analysis (Konar et al., 2018).

\subsection{Color index and whiteness index}

The surface color of dark chocolate samples was measured in triplicate. The CIE Lab color coordinates ( $\mathrm{L}^{*}$ - lightness, $\mathrm{a}^{*}$ - redness to greenness and $\mathrm{b}^{*}$ - yellowness to blueness) were measured using MINOLTA Chroma Meter CR-400 (Minolta Co., Ltd., Osaka, Japan) (Lončarević et al., 2018).

\subsection{Melting properties}

Melting behavior of the dark chocolate samples was determined using DSC (Differential Scanning Calorimeter) (TA Q20, TA Instruments, NewCastle, USA) according to the method pointed out by Glicerina et al. (2013). Samples (5 mg) were put into pans with hermetic lid. The samples were heated from 0 to $60{ }^{\circ} \mathrm{C}$ at $10{ }^{\circ} \mathrm{C} / \mathrm{min}$. Onset temperature (Tonset) and peak temperature (Tpeak) and energy required for the complete melting $(\Delta \mathrm{H})$ of each sample were calculated using correspond thermograms. 


\subsection{Rheological properties}

Flow behavior of the melted dark chocolate samples was determined at $40{ }^{\circ} \mathrm{C}$ using stress or strain controlled rheometer (MCR 302, Anton Paar, Graz, Austria). Cylindrical probe system was applied for the determination of rheological parameters. After melting the chocolate samples at $40{ }^{\circ} \mathrm{C}$, parameters of the Casson model were calculated using the following Equation 2:

$\tau^{0.5}=\tau_{0}^{0.5}+\eta_{p l . \gamma^{n}}$

where $\tau$ is shear stress $(\mathrm{Pa}), \gamma^{\cdot}$ is shear rate $\left(\mathrm{s}^{-}{ }^{1}\right), \tau_{0}$ is the yield stress $(\mathrm{Pa})$ and $\eta_{\mathrm{pl}}$ is plastic viscosity $(\mathrm{Pa} \mathrm{s})$.

\subsection{Particle size distribution}

Particle size distribution was determined according to the method described by Sim et al. 2016 and carried out by laser diffraction particle size analyzer (Horiba, Irvine, California, USA). d50 (mm), d90 (mm) and d10 (mm) were determined (Sim et al., 2016).

\subsection{Sensory properties}

Sensory parameters of the samples were determined with "Multiple Comparison Technique" in chocolate samples (Shah et al., 2010). The sensory evaluation test was performed by ten panelists. Prior to sensory evaluation, panelists were asked to describe their sensory experiences using the following definitions (appearance, aroma and textural properties). Trained panelists evaluated the effects of addition of free or encapsulated chlorogenic acids on sensory characteristics of chocolate samples and consumed water and crackers between tests. Responses were recorded using a hedonic scale where the trained panelists scored from 1 to 7 for different attributes including appearance (blooming, color, surface brightness), texture (firmness), taste (sweetness, acidity, bitter), aroma (metallic taste) and overall acceptance.

\subsection{Statistical analysis}

All data were shown as the averages of triple replicates with standard deviations. Analysis of variance (ANOVA) was carried out using a SPSS program version 16.0 (SPSS Inc., Chicago, IL, USA). Duncan's multiple range tests were used to examine the significant differences among the means of treatments $(p \leq 0.05)$.

Table 1. Definition of tested samples.

\begin{tabular}{|c|c|c|c|}
\hline Samples & Code & Samples & Code \\
\hline Control (without chlorogenic acids) & A0 & Control (without chlorogenic acids) & $\mathrm{A} 0$ \\
\hline $\begin{array}{l}\text { Dark chocolate enriched with free } \\
\text { chlorogenic acids }(10 \mathrm{mg} / 5 \mathrm{~kg})\end{array}$ & A1 & $\begin{array}{l}\text { Dark chocolate enriched with encapsulated } \\
\text { chlorogenic acids }(10.02 \mathrm{mg} / 5 \mathrm{~kg})\end{array}$ & AE1 \\
\hline $\begin{array}{l}\text { Dark chocolate enriched with free } \\
\text { chlorogenic acids }(20 \mathrm{mg} / 5 \mathrm{~kg})\end{array}$ & A2 & $\begin{array}{l}\text { Dark chocolate enriched with encapsulated } \\
\text { chlorogenic acids }(20.05 \mathrm{mg} / 5 \mathrm{~kg})\end{array}$ & AE2 \\
\hline $\begin{array}{l}\text { Dark chocolate enriched with free } \\
\text { chlorogenic acids }(30 \mathrm{mg} / 5 \mathrm{~kg})\end{array}$ & A3 & $\begin{array}{l}\text { Dark chocolate enriched with encapsulated } \\
\text { chlorogenic acids }(30.08 \mathrm{mg} / 5 \mathrm{~kg})\end{array}$ & AE3 \\
\hline $\begin{array}{l}\text { Dark chocolate enriched with free } \\
\text { chlorogenic acids }(40 \mathrm{mg} / 5 \mathrm{~kg})\end{array}$ & A4 & $\begin{array}{l}\text { Dark chocolate enriched with encapsulated } \\
\text { chlorogenic acids }(40.11 \mathrm{mg} / 5 \mathrm{~kg})\end{array}$ & AE4 \\
\hline $\begin{array}{l}\text { Dark chocolate enriched with free } \\
\text { chlorogenic acids }(50 \mathrm{mg} / 5 \mathrm{~kg})\end{array}$ & A5 & $\begin{array}{l}\text { Dark chocolate enriched with encapsulated } \\
\text { chlorogenic acids }(50.14 \mathrm{mg} / 5 \mathrm{~kg})\end{array}$ & AE5 \\
\hline
\end{tabular}




\section{Results and discussions}

\subsection{Encapsulation efficiency}

After measuring the chlorogenic acids content in microcapsules, the encapsulation efficiency calculated was of approximately $99.71 \%$. This result implies that the encapsulation method chosen for this study has a desirable efficiency. This result was in accordance with other studies that reported high encapsulation efficiency. Outuki et al. (2016) reported the encapsulation efficiency for encapsulation extract of Eschweilera nana Miers leaves by Arabic and xanthan gum wall material equal to $98.58 \% \pm 0.69 \%$.

\subsection{FTIR}

Figure 1 shows FTIR spectra of the chlorogenic acid and encapsulated chlorogenic acids. Accordingly, the remarkable peaks appeared at 3468 and $3344 \mathrm{~cm}^{-1}$ which are attributed to $\mathrm{OH}$ groups. The presence of phenol functional groups was affirmed but there was a peak at $1383 \mathrm{~cm}^{-1}$ and $1443 \mathrm{~cm}^{-1}$. Peak observed at $1726 \mathrm{~cm}^{-1}$ corresponded to ascending $\mathrm{C}=\mathrm{O}$ vibration of the carboxylic groups but peak at $1687 \mathrm{~cm}^{-1}$ is due to $\mathrm{C}=\mathrm{O}$ vibrations of the ester groups. $\mathrm{C}=\mathrm{C}$ bonds cause a peak at $1639 \mathrm{~cm}^{-1}$ and peal of $1600^{-1}$ is resulted from aromatic ring. The presence of aromatic structure was confirmed by peaks at $1321 \mathrm{~cm}^{-1}$, 818 and $602 \mathrm{~cm}^{-1}$ (Catauro \& Pacifico, 2017).

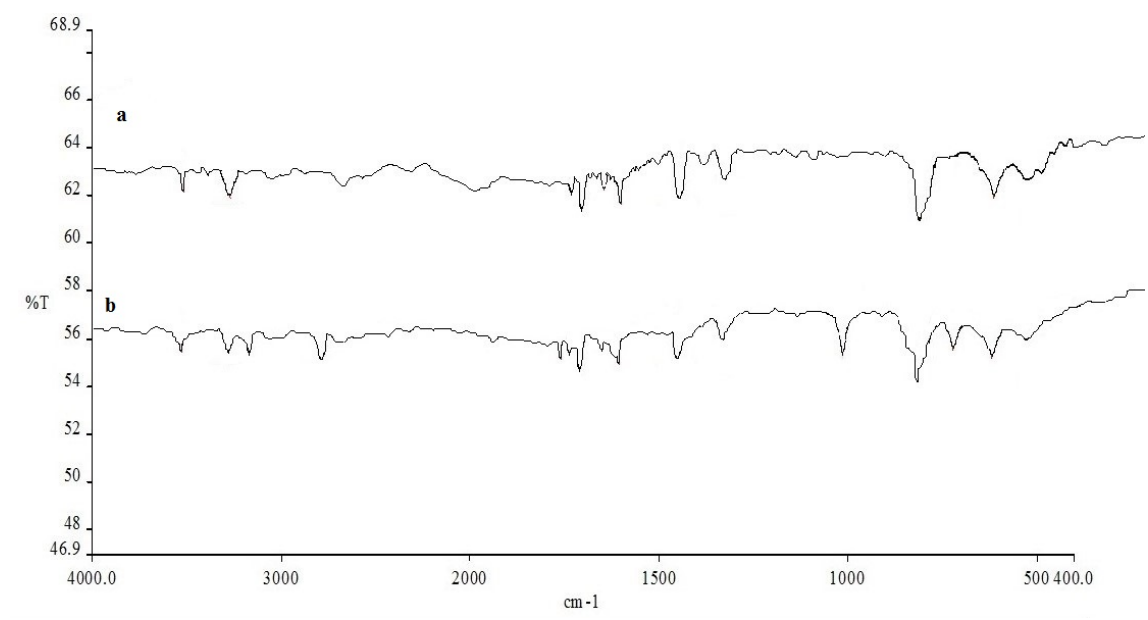

Figure 1. The FTIR spectrum of chlorogenic acids (a) and encapsulated chlorogenic acids (b).

Figure 1b shows the FTIR spectrum of encapsulated chlorogenic acids by gelatin- pectin wall materials. Accordingly, the FTIR spectrum showed some more peaks due to the presence of functional groups in the wall materials of capsules. The main obvious peaks appeared at 1010,1750 and $3253 \mathrm{~cm}^{-1}$ which are ascending to C-O bending vibration, carbonyl and hydroxyl group of pectin (Namanga et al., 2013) and other main peaks included peaks appeared at 2900 (resulted from C-H group vibration of protein) and $700 \mathrm{~cm}^{-1}$ which attributed to gelatin structure (Pradini et al., 2018).

\subsection{SEM}

SEM observation of microcapsules revealed the encapsulation process was successfully done and microcapsules formed (Figure 2). These observations along with FTIR analysis affirmed the encapsulation of chlorogenic acids was thoroughly performed. 
a

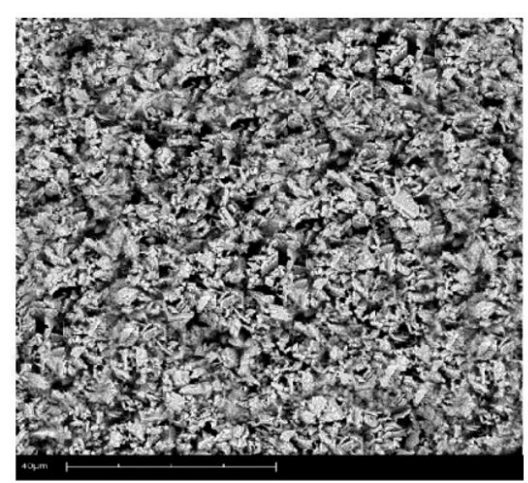

b

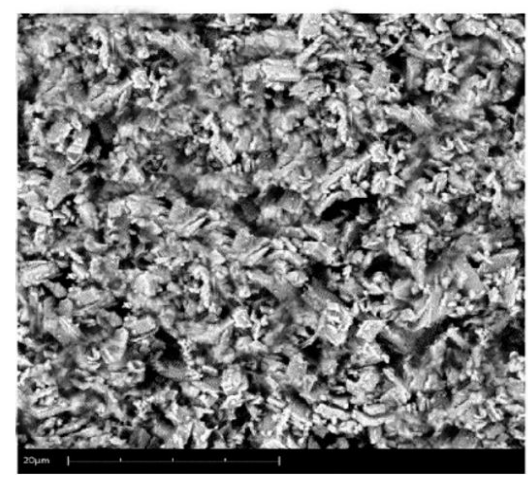

Figure 2. SEM images of encapsulated chlorogenic acids at magnification of 3000 (a) and 5000 (b).

\subsection{Thermal properties}

Table 2 shows DSC parameters - onset temperature $\left(\mathrm{T}_{\text {onset }}\right)$, peak temperature $\left(\mathrm{T}_{\text {peak }}\right)$, and $\Delta \mathrm{H}$. The addition of chlorogenic acids (both free and encapsulated) affects $\mathrm{T}_{\text {onset }}$ values of enriched chocolates at high concentrations which are significantly $(p<0.05)$ lower compared to control. Moreover, $\mathrm{T}_{\text {peak }}$ values of A4, A5, AE4 and AE5, were significantly $(p<0.05)$ lower than $\mathrm{T}_{\text {peak }}$ value of control sample. These observations can be explained by increasing of thin layers of fat phase which cover a larger specific surface area of particles in chocolate when chlorogenic acids is added to chocolate formulation. The effect of adding encapsulated materials to chocolate formulation on DSC parameters is reported by Lončarević et al. (2018), who mentioned that the addition of encapsulated blackberry juice resulted in decrease of $\mathrm{T}_{\text {onset }}$ values.

Table 2. Melting properties of dark chocolates enriched with chlorogenic acids (free or encapsulated).

\begin{tabular}{cccccccc}
\hline Sample code & $\mathbf{T}_{\text {onset }}\left({ }^{\circ} \mathbf{C}\right)$ & $\mathbf{T}_{\text {peak }}\left({ }^{\circ} \mathbf{C}\right)$ & $\Delta \mathbf{H}(\mathbf{J} / \mathbf{g})$ & Sample code & $\mathbf{T}_{\text {onset }}\left({ }^{\circ} \mathbf{C}\right)$ & $\mathbf{T}_{\text {peak }}\left({ }^{\circ} \mathbf{C}\right)$ & $\Delta \mathbf{H}(\mathbf{J} / \mathbf{g})$ \\
\hline A0 & $31 \pm 0.2^{\mathrm{a}}$ & $33.7 \pm 0.1^{\mathrm{a}}$ & $3.15 \pm 0.3^{\mathrm{a}}$ & A0 & $31 \pm 0.2^{\mathrm{a}}$ & $33.7 \pm 0.1^{\mathrm{a}}$ & $3.15 \pm 0.3^{\mathrm{a}}$ \\
\hline A1 & $30.6 \pm 1^{\mathrm{a}}$ & $33 \pm 0.1^{\mathrm{a}}$ & $3 \pm 0.2^{\mathrm{a}}$ & AE1 & $31 \pm 0.2^{\mathrm{a}}$ & $33 \pm 0.2^{\mathrm{b}}$ & $3.1 \pm 0.2^{\mathrm{a}}$ \\
\hline A2 & $30.2 \pm 0.2^{\mathrm{a}}$ & $32.5 \pm 0.2^{\mathrm{a}}$ & $2.8 \pm 0.1^{\mathrm{a}}$ & AE2 & $30.8 \pm 0.1^{\mathrm{a}}$ & $32.6 \pm 0.2^{\mathrm{c}}$ & $3 \pm 0.1^{\mathrm{a}}$ \\
\hline A3 & $291 \pm 0.2^{\mathrm{b}}$ & $31.3 \pm 0.2^{\mathrm{b}}$ & $2.5 \pm 0.1^{\mathrm{b}}$ & AE3 & $30.4 \pm 0.2^{\mathrm{a}}$ & $32.5 \pm 0.1^{\mathrm{c}}$ & $2.8 \pm 0.1^{\mathrm{b}}$ \\
\hline A4 & $284 \pm 0.1^{\mathrm{b}}$ & $30.6 \pm 0.1^{\mathrm{b}}$ & $2.1 \pm 0.1^{\mathrm{c}}$ & AE4 & $29.3 \pm 0.1^{\mathrm{b}}$ & $32.1 \pm 0.1^{\mathrm{c}}$ & $2.6 \pm 0.1^{\mathrm{bc}}$ \\
\hline A5 & $27.8 \pm 0.1^{\mathrm{c}}$ & $30 \pm 0.2^{\mathrm{c}}$ & $1.8 \pm 0.2^{\mathrm{d}}$ & AE5 & $28.9 \pm 0.2^{\mathrm{c}}$ & $31.9 \pm 0.3^{\mathrm{d}}$ & $2.4 \pm 0.1^{\mathrm{c}}$ \\
\hline
\end{tabular}

Different superscript lowercase letters show the significant differences between the samples $(p<0.05)$. ( $\left(\mathrm{T}_{\text {onset }}\right.$, onset temperature; $T_{\text {peak, }}$, peak temperature; $\Delta \mathrm{H}$, energy required for the complete melting of the samples) experiments were performed in triplicate.

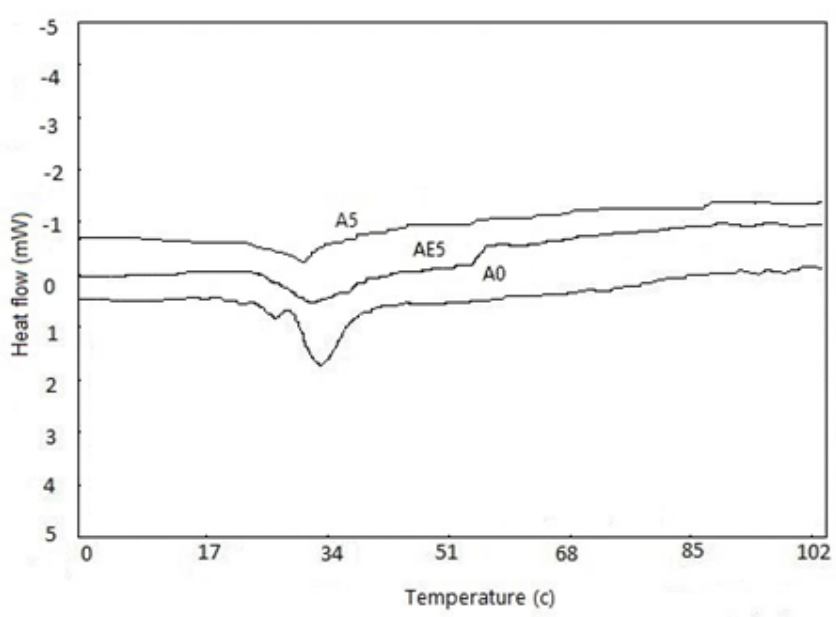

Figure 3. Thermogram of dark chocolate samples. 
Figure 3 exhibits the DSC curves of dark chocolate samples. The control sample starts to melt at higher temperature than the other samples. This means that the majority of fat was melted above room temperature and explains the distinctive hard texture than other samples.

Otherwise, the dark chocolate samples enriched with chlorogenic acids (free or encapsulate form) melted at lower temperature (Table 2).

Furthermore, $\mathrm{T}_{\text {peak }}$ values of enriched samples at high concentration of chlorogenic acids significantly differ compared to control. $\Delta \mathrm{H}$ energy required for the complete melting of the samples were also lower than control sample. These observations are attributable to the most compact structure of control sample and enriched samples with encapsulated chlorogenic acids than samples enriched with free chlorogenic acid. A reason which explains these observations is the effect of enriched material on fat crystallization and fat network formation.

\subsection{Color}

Table 3 shows the lightness $\left(\mathrm{L}^{*}\right)$, red tone $\left(\mathrm{a}^{*}\right)$, and yellow tone $\left(\mathrm{b}^{*}\right)$ measured on the surface of dark chocolate samples and results. Enriched chocolate with free chlorogenic acids had lower $L^{*}$ value than control sample but enriched chocolate with encapsulated chlorogenic acids had higher $\mathrm{L}^{*}$ value than control sample $(p<0.05)$ (Table3).

$a^{*}$ value had no differences among all samples (control or enriched). $b^{*}$ values of enriched chocolate samples with free chlorogenic acids were higher than control sample but $b^{*}$ values of enriched chocolate samples with encapsulated chlorogenic acids were lower than control sample (Table 3). This observation showed addition chlorogenic acids in free form cause decreasing in lightness ( $\mathrm{L}^{*}$ value) of resulted chocolate as well as increasing yellowness ( $b^{*}$ values) of dark chocolate samples. Although, addition of encapsulated chlorogenic acids into dark chocolate resulted increasing lightness of dark chocolate ( $\mathrm{L}^{*}$ value) as well as decreasing yellowness ( $b *$ values) of dark chocolate samples (Table 3).

The color of chocolate was affected by several factors, such as processing parameters, the nature of added substances to formulation and crystal structure (Lindecrantz, 2014). According to the obtained results, the addition of chlorogenic acid (free or encapsulated) had little effect on color index of dark chocolate.

Table 3. The Color index of dark chocolate samples.

\begin{tabular}{cccccccc}
\hline $\begin{array}{c}\text { Sample } \\
\text { code }\end{array}$ & $\mathbf{L}^{*}$ & $\mathbf{a}^{*}$ & $\mathbf{b}^{*}$ & $\begin{array}{c}\text { Sample } \\
\text { code }\end{array}$ & $\mathbf{L}^{*}$ & $\mathbf{a}^{*}$ & $\mathbf{b}^{*}$ \\
\hline A0 & $32.5 \pm 0.03 \mathrm{a}$ & $12.85 \pm 0.01^{\mathrm{a}}$ & $13.42 \pm 0.02^{\mathrm{b}}$ & A0 & $32.5 \pm 0.03^{\mathrm{b}}$ & $12.75 \pm 0.01^{\mathrm{d}}$ & $14.42 \pm 0.02^{\mathrm{a}}$ \\
\hline $\mathrm{A} 1$ & $32.4 \pm 0.02^{\mathrm{a}}$ & $12.84 \pm 0.001^{\mathrm{a}}$ & $13.5 \pm 0.03^{\mathrm{b}}$ & AE1 & $33 \pm 0.05^{\mathrm{b}}$ & $-12.73 \pm 0.001^{\mathrm{a}}$ & $13.6 \pm 0.03^{\mathrm{b}}$ \\
\hline A2 & $32.2 \pm 0.04^{\mathrm{a}}$ & $12.83 \pm 0.002^{\mathrm{a}}$ & $13 \pm 0.02^{\mathrm{b}}$ & AE2 & $33.2 \pm 0.04^{\mathrm{a}}$ & $12.72 \pm 0.002^{\mathrm{a}}$ & $13.6 \pm 0.02^{\mathrm{b}}$ \\
\hline A3 & $32 \pm 0.01^{\mathrm{a}}$ & $12.82 \pm 0.002^{\mathrm{a}}$ & $13.5 \pm 0.02^{\mathrm{b}}$ & AE3 & $33.5 \pm 0.04^{\mathrm{a}}$ & $12.71 \pm 0.001^{\mathrm{a}}$ & $13.4 \pm 0.03^{\mathrm{b}}$ \\
\hline A4 & $31.2 \pm 0.01^{\mathrm{b}}$ & $12.81 \pm 0.003^{\mathrm{a}}$ & $14 \pm 0.03^{\mathrm{a}}$ & AE4 & $33.7 \pm 0.02^{\mathrm{a}}$ & $12.68 \pm 0.002^{\mathrm{a}}$ & $13.03 \pm 0.01^{\mathrm{b}}$ \\
\hline A5 & $31.8 \pm 0.02^{\mathrm{b}}$ & $12.81 \pm 0.002^{\mathrm{a}}$ & $14.13 \pm 0.02^{\mathrm{a}}$ & AE5 & $33.8 \pm 0.02^{\mathrm{a}}$ & $12.67 \pm 0.001^{\mathrm{a}}$ & $13.2 \pm 0.01^{\mathrm{b}}$ \\
\hline
\end{tabular}

Different superscript lowercase letters show the significant differences between the samples $(p<0.05)$.

\subsection{Particle size distribution}

Table 4 shows the particle size distribution parameters of dark chocolates. Dark chocolate is a product with multimodal particle size distribution. Desirable particles in chocolate should be in interval 15 to $30 \mu \mathrm{m}$ (Bolenz et al., 2014), as in Table 4, the enriched dark chocolate with free chlorogenic acids has a lower percentage of particles with diameters in interval 15-30 $\mu \mathrm{m}$ compared to control $(p<0.05)$. In general, enriched samples with free chlorogenic acids had lower particle sizes compared to control sample and this effect was in accordance with the concentrations of added chlorogenic acid. 
Addition of encapsulated chlorogenic acids also influences the particle size distribution parameters of dark chocolate (increasing particle size). This phenomenon could be due to gelatin-pectin coating of chlorogenic acids.

Table 4. Particle size distribution of dark chocolate samples.

\begin{tabular}{cccccccc}
\hline $\begin{array}{c}\text { Sample } \\
\text { code }\end{array}$ & $\mathbf{d}(\mathbf{0 . 1})$ & $\mathbf{d}(\mathbf{0 . 5})$ & $\mathbf{d}(\mathbf{0 . 9})$ & $\begin{array}{c}\text { Sample } \\
\text { code }\end{array}$ & $\mathbf{d}(\mathbf{0 . 1})$ & $\mathbf{d}(\mathbf{0 . 5 )}$ & $\mathbf{d ( 0 . 9 )}$ \\
\hline A0 & $2.57 \pm 0.01^{\mathrm{a}}$ & $9.16 \pm 0.03^{\mathrm{a}}$ & $29.21 \pm 0.02^{\mathrm{a}}$ & A0 & $2.57 \pm 0.01^{\mathrm{c}}$ & $9.16 \pm 0.03^{\mathrm{d}}$ & $29.21 \pm 0.02^{\mathrm{f}}$ \\
\hline A1 & $2.51 \pm 0.02^{\mathrm{a}}$ & $9 \pm 0.03^{\mathrm{a}}$ & $28.4 \pm 0.04^{\mathrm{b}}$ & AE1 & $2.59 \pm 0.02^{\mathrm{c}}$ & $9.64 \pm 0.04^{\mathrm{c}}$ & $30.20 \pm 0.03^{\mathrm{e}}$ \\
\hline A2 & $2.42 \pm 0.02^{\mathrm{b}}$ & $8.66 \pm 0.04^{\mathrm{b}}$ & $28.1 \pm .03^{\mathrm{b}}$ & AE2 & $2.62 \pm .03^{\mathrm{c}}$ & $10.2 \pm 0.04^{\mathrm{b}}$ & $32.3 \pm 0.02^{\mathrm{d}}$ \\
\hline A3 & $2.34 \pm 0.01^{\mathrm{c}}$ & $8.61 \pm 0.04^{\mathrm{b}}$ & $27.3 \pm 0.04^{\mathrm{c}}$ & AE3 & $2.71 \pm 0.03^{\mathrm{b}}$ & $10.6 \pm 0.03^{\mathrm{b}}$ & $35 \pm 0.03^{\mathrm{c}}$ \\
\hline A4 & $2.26 \pm 0.02^{\mathrm{d}}$ & $8.60 \pm 0.05^{\mathrm{b}}$ & $27 \pm 0.05^{\mathrm{c}}$ & AE4 & $2.81 \pm 0.04^{\mathrm{a}}$ & $11.3 \pm 0.04^{\mathrm{a}}$ & $38.4 \pm 0.04^{\mathrm{b}}$ \\
\hline A5 & $2.21 \pm 0.01^{\mathrm{e}}$ & $8.53 \pm 0.01^{\mathrm{c}}$ & $26.6 \pm 0.03^{\mathrm{c}}$ & AE5 & $2.96 \pm 0.02^{\mathrm{a}}$ & $12 \pm 0.01^{\mathrm{a}}$ & $41.4 \pm 0.02^{\mathrm{a}}$ \\
\hline
\end{tabular}

Different superscript lowercase letters show the significant differences between the samples $(p<0.05)$.

Bigger particles often cause a gritty mouth feeling and smaller particles increase the specific surface area, more liquid phase is needed to cover it and resulted in increasing the viscosity of molten chocolate at the same time (Bolenz et al., 2014).

\subsection{Rheological properties}

Table 5 shows the impact of added chlorogenic acids (free or encapsulated) on rheological properties of enriched chocolates.

Table 5. Rheological parameters of dark chocolate and enriched chocolates.

\begin{tabular}{|c|c|c|c|c|c|}
\hline $\begin{array}{c}\text { Sample } \\
\text { code }\end{array}$ & $\begin{array}{c}\text { Casson yield stress } \\
(\mathrm{Pa})\end{array}$ & $\begin{array}{c}\text { Casson viscosity } \\
\text { (Pas) }\end{array}$ & $\begin{array}{c}\text { Sample } \\
\text { code }\end{array}$ & $\begin{array}{c}\text { Casson yield stress } \\
\text { (Pa) }\end{array}$ & $\begin{array}{c}\text { Casson viscosity } \\
\text { (Pas) }\end{array}$ \\
\hline $\mathrm{A} 0$ & $21.29 \pm 0.1^{\mathrm{a}}$ & $1.26 \pm 0.02^{\mathrm{c}}$ & $\mathrm{A} 0$ & $21.29 \pm 0.1^{\mathrm{d}}$ & $1.26 \pm 0.1^{\mathrm{b}}$ \\
\hline $\mathrm{A} 1$ & $21.05 \pm 0.11^{\mathrm{b}}$ & $1.44 \pm 0.01^{\mathrm{b}}$ & AE1 & $21.48 \pm 0.13^{\mathrm{c}}$ & $1.38 \pm 0.12^{\mathrm{a}}$ \\
\hline $\mathrm{A} 2$ & $18.84 \pm 0.12^{\mathrm{c}}$ & $1.44 \pm 0.01^{\mathrm{b}}$ & AE2 & $21.51 \pm 0.11^{\mathrm{c}}$ & $1.38 \pm 0.13^{\mathrm{a}}$ \\
\hline A3 & $18.84 \pm 0.1^{\mathrm{c}}$ & $1.44 \pm 0.01^{\mathrm{b}}$ & AE3 & $21.57 \pm 0.12^{\mathrm{c}}$ & $1.38 \pm 0.11^{\mathrm{a}}$ \\
\hline A4 & $18.84 \pm 0.12^{\mathrm{c}}$ & $1.47 \pm 0.01^{\mathrm{b}}$ & AE4 & $21.7 \pm 0.12^{\mathrm{b}}$ & $1.35 \pm 0.12^{\mathrm{a}}$ \\
\hline A5 & $18.48 \pm 0.12^{\mathrm{c}}$ & $1.5 \pm 0.02^{\mathrm{a}}$ & AE5 & $21.89 \pm 0.12^{\mathrm{b}}$ & $1.35 \pm 0.12^{\mathrm{a}}$ \\
\hline
\end{tabular}

The addition of chlorogenic acids (both free and encapsulated) increased viscosity of dark chocolate mass in accordance with the added concentration (Table 5). These results match with other research in this context. Toker et al. (2018) reported that the addition of components of lipophilic nature causes increasing casson viscosity. The addition of encapsulated chlorogenic acids had slight impact on rheological parameters and this phenomenon is important from technology and processing viewpoint. The lower viscosity of chocolate resulted in easier processing of it (Toker et al., 2018).

Figures 2 and 3 show the flow behavior of dark chocolate samples as chlorogenic acids (free or encapsulated) were added. Chocolate rheology was affected by several factors (process condition, ingredient composition, fat content, choice of emulsifier, solid particle size distribution and the method of particle packing) (Pajin et al., 2013). All tested chocolate samples showed a thixotropic flow behavior.

As it is evident, the addition of chlorogenic acids to dark chocolate formulation resulted in changes in flow behavior. The addition of free chlorogenic acids caused lower shear stress in produced chocolate (Figure 4) but the addition of encapsulated chlorogenic acids caused more shear stress in related dark chocolate (Figure 5). 


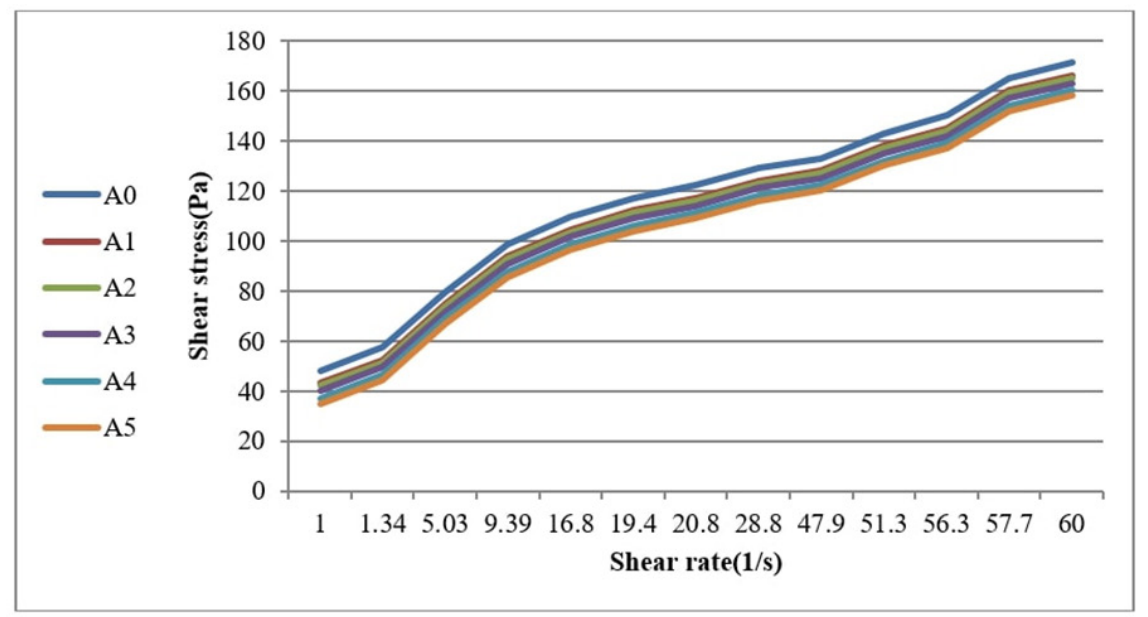

Figure 4. Flow curves of dark chocolate samples, showing shear stress as a function of shear rate.

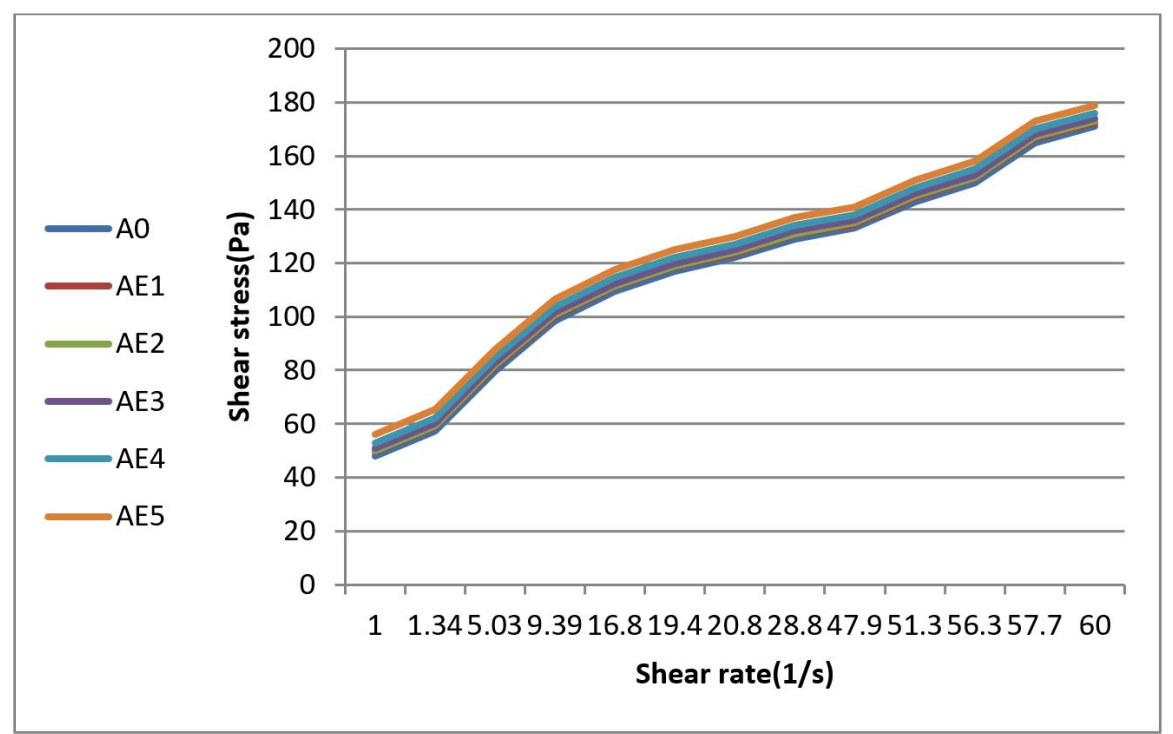

Figure 5. Flow curves of dark chocolate samples, showing shear stress as a function of shear rate.

\subsection{Appearance and microstructural examination}

According to SEM images, the addition of encapsulated chlorogenic acids also influenced the appearance of the samples (included $50 \mathrm{mg} / 5 \mathrm{~kg}$ ) in SEM images, which spatial distribution of uniform dense crystalline network within the structure was apparent (Figure 6). In other cases, a more uniform structure was observed. 
A
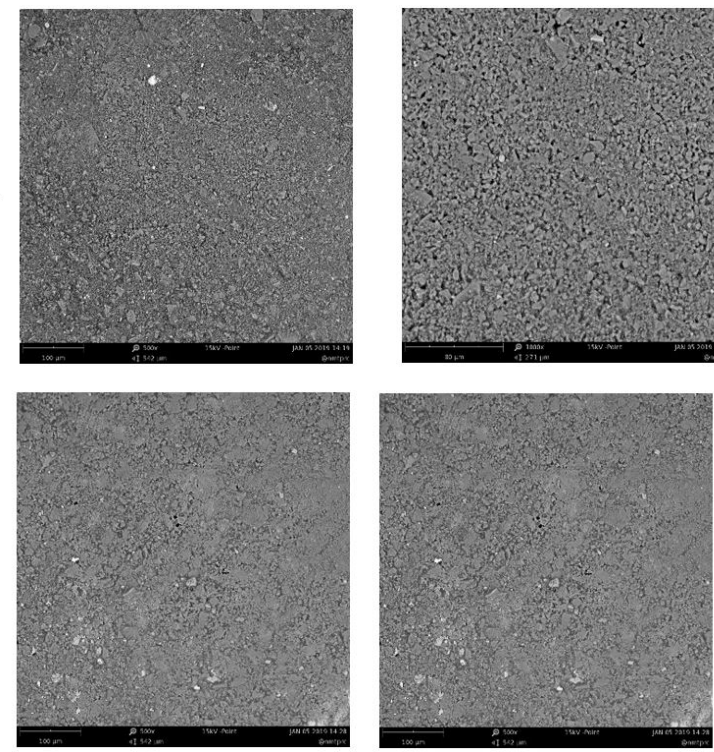
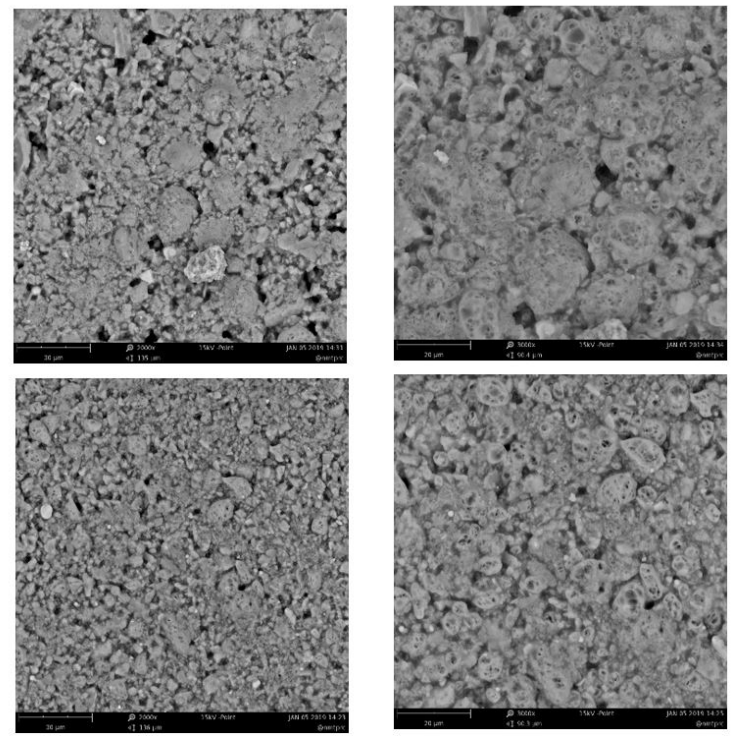

Figure 6. SEM images of Dark chocolate. (A) $50.14 \mathrm{mg} / 5 \mathrm{~kg}$ encapsulated chlorogenic acids; (B) $50 \mathrm{mg} / 5 \mathrm{~kg}$ free chlorogenic acids).

\subsection{Sensory evaluation}

The addition of chlorogenic acids (both free and encapsulated) had no significant effect on dark chocolate color (Table6). The addition of encapsulated and free chlorogenic acids cause lower hardness of chocolate than control one. The addition of free or encapsulated chlorogenic acids had a significant impact $(p<0.05)$ on chocolate flavor. The flavor score of all chocolate samples decreased as free chlorogenic acids were added. In the case of 40 and $50 \mathrm{mg} / 5 \mathrm{~kg}$ free chlorogenic acids addition, panelists also distinguished changes in flavor. The adverse effect of chlorogenic acids on chocolate flavor were lower in the case of the addition of encapsulated form (Table 6). Microencapsulation could mask unpleasant taste of natural antioxidants (Aguiar et al., 2016). 
Properties of dark chocolate enriched with free and encapsulated chlorogenic acids extracted from green coffee

Didar, $Z$.

Table 6. Sensory properties of dark chocolate samples.

\begin{tabular}{|c|c|c|c|c|c|c|c|c|c|c|c|}
\hline \multicolumn{12}{|c|}{ Sample code } \\
\hline Sensory properties & A0 & A1 & A2 & A3 & A4 & A5 & AE1 & AE2 & AE3 & AE4 & AE5 \\
\hline Blooming & $1 \pm 0.00^{\mathrm{h}}$ & $2.5 \pm 0.03^{\mathrm{e}}$ & $3 \pm 0.02^{\mathrm{d}}$ & $4 \pm 0.02^{c}$ & $4.5 \pm 0.04^{b}$ & $5 \pm 0.03^{\mathrm{a}}$ & $1.3 \pm 0.02^{\mathrm{g}}$ & $1.5 \pm 0.03^{\mathrm{g}}$ & $2 \pm 0.01^{\mathrm{f}}$ & $2.5 \pm 0.02^{\mathrm{e}}$ & $3 \pm 0.02^{\mathrm{d}}$ \\
\hline Surface brightness & $6.7 \pm 0.02^{\mathrm{a}}$ & $4 \pm 0.02^{c}$ & $3.8 \pm 0.01^{\mathrm{c}}$ & $3.5 \pm 0.01^{\mathrm{c}}$ & $3 \pm 0.01^{\mathrm{d}}$ & $2 \pm 0.01^{\mathrm{e}}$ & $5.2 \pm 0.02^{b}$ & $5.2 \pm 0.02^{b}$ & $5 \pm 0.03^{b}$ & $4 \pm 0.01^{\mathrm{c}}$ & $3.8 \pm 0.00^{\mathrm{c}}$ \\
\hline Color & $6.8 \pm 0.02^{\mathrm{a}}$ & $6.5 \pm 0.01^{\mathrm{a}}$ & $6.5 \pm 0.04^{\mathrm{a}}$ & $6.2 \pm 0.01^{\mathrm{a}}$ & $6 \pm 0.03^{\mathrm{a}}$ & $6 \pm 0.03^{a}$ & $6.5 \pm 0.04^{\mathrm{a}}$ & $6.5 \pm 0.02^{\mathrm{a}}$ & $6.5 \pm 0.03^{\mathrm{a}}$ & $6.4 \pm 0.01^{\mathrm{a}}$ & $6.3 \pm 0.01^{\mathrm{a}}$ \\
\hline Hardness & $6.7 \pm 0.01^{\mathrm{a}}$ & $3.5 \pm 0.00^{\mathrm{d}}$ & $3 \pm 0.01^{\mathrm{e}}$ & $2.8 \pm 0.02^{\mathrm{e}}$ & $2.5 \pm 0.02^{\mathrm{f}}$ & $2 \pm 0.02^{g}$ & $4.3 \pm 0.02^{\mathrm{c}}$ & $4.2 \pm 0.03^{\mathrm{c}}$ & $4.5 \pm 0.01^{\mathrm{c}}$ & $4.8 \pm 0.01^{\mathrm{b}}$ & $5 \pm 0.01^{\mathrm{b}}$ \\
\hline Acidity & $6 \pm 0.03^{\mathrm{a}}$ & $4.5 \pm 0.02^{b}$ & $3.8 \pm 0.01^{\mathrm{c}}$ & $2.3 \pm 0.03^{\mathrm{d}}$ & $1.9 \pm 0.01^{\mathrm{e}}$ & $1 \pm 0.01^{\mathrm{f}}$ & $0.92 \pm 0.01^{\mathrm{f}}$ & $0.9 \pm 0.01^{\mathrm{f}}$ & $1 \pm 0.00^{\mathrm{f}}$ & $1.5 \pm 0.01$ & $1.8 \pm 0.01$ \\
\hline Bitterness & $1 \pm 0.02^{\mathrm{f}}$ & $1.5 \pm 0.00^{\mathrm{e}}$ & $2.5 \pm 0.04^{\mathrm{d}}$ & $3.5 \pm 0.04^{\mathrm{c}}$ & $4.5 \pm 0.03^{b}$ & $5 \pm 0.02^{\mathrm{a}}$ & $1.5 \pm 0.02^{\mathrm{e}}$ & $1.5 \pm 0.03^{\mathrm{e}}$ & $1.7 \pm 0.01^{\mathrm{e}}$ & $1.8 \pm 0.01^{\mathrm{e}}$ & $2 \pm 0.00^{\mathrm{e}}$ \\
\hline Metallic taste & $1 \pm 0.02^{\mathrm{f}}$ & $1.5 \pm 0.00^{\mathrm{d}}$ & $2.5 \pm 0.04^{\mathrm{c}}$ & $3.5 \pm 0.03^{b}$ & $4.5 \pm 0.03^{\mathrm{a}}$ & $4.8 \pm 0.02^{\mathrm{a}}$ & $1 \pm 0.01^{\mathrm{f}}$ & $1 \pm 0.02^{\mathrm{f}}$ & $1 \pm 0.01^{\mathrm{f}}$ & $1.3 \pm 0.00^{\mathrm{e}}$ & $1.5 \pm 0.01^{\mathrm{d}}$ \\
\hline Overall Acceptability & $6.8 \pm 0.02^{\mathrm{a}}$ & $4.5 \pm 0.01^{\mathrm{d}}$ & $4.1 \pm 0.02^{\mathrm{e}}$ & $4 \pm 0.02^{\mathrm{e}}$ & $3 \pm 0.02^{g}$ & $3 \pm 0.02^{g}$ & $5.1 \pm 0.01^{b}$ & $5.2 \pm 0.02^{b}$ & $5 \pm 0.02^{c}$ & $4 \pm 0.03^{\mathrm{e}}$ & $3.7 \pm 0.02^{\mathrm{f}}$ \\
\hline
\end{tabular}

Different superscript lowercase letters show the significant differences between the samples $(p<0.05)$. 


\section{Conclusions}

Chlorogenic acids are strong antioxidant found in different plant material. Results showed that the addition of free and encapsulated forms of chlorogenic acids decreased $\mathrm{T}_{\text {onset, }} \mathrm{T}_{\text {peak }}$ and $\Delta \mathrm{H}$ of dark chocolate. Casson viscosity increased in the case of chlorogenic acids addition.

Particle size distribution decreased with the addition of free form and increased in the case of encapsulated form. Sensory scores were also influenced by chocolate formulation and samples containing encapsulated chlorogenic acids had better sensory properties than samples enriched with free form. The best samples were those containing 10.02 and $20.05 \mathrm{mg} / 5 \mathrm{~kg}$ of encapsulated chlorogenic acids.

\section{References}

Afoakwa, E. O. (2010). Chocolate science and technology. Oxford: Wiley- Blackwell. http://dx.doi.org/10.1002/9781444319880.

Aguiar, J., Estevinho, B. N., \& Santos, L. (2016). Microencapsulation of natural antioxidants for food application: The specific case of coffee antioxidants: A review. Trends in Food Science \& Technology, 58, 21-39.

http://dx.doi.org/10.1016/j.tifs.2016.10.012

Ballesteros, L. F., Ramirez, M. J., Orrego, C. E., Teixeira, J. A., \& Mussatto, S. I. (2017). Encapsulation of antioxidant phenolic compounds extracted from spent coffee grounds by freeze-drying and spray-drying using different coating materials. Food Chemistry, 237, 623-631. PMid:28764044. http://dx.doi.org/10.1016/j.foodchem.2017.05.142

Belay, A., \& Gholap, A. V. (2009). Characterization and determination of chlorogenic acids (CGA) in coffee beans by UV-Vis spectroscopy. African Journal of Pure and Applied Chemistry, 3(11), 234-240.

Bolenz, S., Holm, M., \& Langkrär, C. (2014). Improving particle size distribution and flow properties of milk chocolate produced by ball mill and blending. European Food Research and Technology, 238(1), 139-147. http://dx.doi.org/10.1007/s00217-0132094-7

Carocho, M., Morales, P., \& Ferreira, I. C. (2018). Antioxidants: Reviewing the chemistry, food applications, legislation and role as preservatives. Trends in Food Science \& Technology, 71, 107-120. http://dx.doi.org/10.1016/j.tifs.2017.11.008

Catauro, M., \& Pacifico, S. (2017). Synthesis of bioactive chlorogenic acid-silica hybrid materials via the sol-gel route and evaluation of their biocompatibility. Materials, 10(7), 840-853. PMid:28773198. http://dx.doi.org/10.3390/ma10070840

Cheraghali, F., Mirmoghtadaie, L., Shojaee-Aliabadi, S., \& Hosseini, S. M. (2016). A comprative study of antimicrobial and antioxidant properties of walnut green husk aqueous extract before and after microencapsulation. Iranian Journal of Nutrition Sciences and Food Technology, 11(2), 113-124.

Glicerina, V., Balestra, F., Rosa, M. D., \& Romani, S. (2013). Rheological, textural and calorimetric modifications of dark chocolate during process. Journal of Food Engineering, 119(1), 173-179. http://dx.doi.org/10.1016/j.jfoodeng.2013.05.012

Jain, A., Thakur, D., Ghoshal, G., Katare, O. P., Singh, B., \& Shivhare, U. S. (2016). Formation and functional attributes of electrostatic complexes involving casein and anionic polysaccharides: An approach to enhance oral absorption of lycopene in rats in vivo. International Journal of Biological Macromolecules, 93(Pt A), 746-756. PMid:27575434. http://dx.doi.org/10.1016/j.ijbiomac.2016.08.071

Kemsawasd, V., Chaikham, P., \& Rattanasena, P. (2016). Survival of immobilized probiotics in chocolate during storage and with an in vitro gastrointestinal model. Food Bioscience, 16, 37-43. http://dx.doi.org/10.1016/j.fbio.2016.09.001

Kiomarsi, M., Yeganeh Zad, S., Shahidi, S., Pahlavanloo, A., \& Khosh Kish, M. (2017). Optimization of prebiotic dark chocolate formulation by inulin, isomal and maltitol. Journal of Innovation in Food Science, 9(3), 73-86.

Konar, N., Palabiyik, I., Toker, O. S., Polat, D. G., Kelleci, E., Pirouzian, H. R., Akcicek, A., \& Sagdic, O. (2018). Conventional and sugar-free probiotic white chocolate: Effect of inulin DP on various quality properties and viability of probiotics. Journal of Functional Foods, 43, 206-213. http://dx.doi.org/10.1016/j.jf.2018.02.016

Lindecrantz, A. (2014). Investigation of seedpowder technology for pre-crystallization processing for dark chocolate: Effect on fat crystal structure and storage stability (Master's thesis). Chalmers University of Technology, Gothenburg, Sweden.

Lončarević, I., Pajin, B., Fišteš, A., Tumbas Šaponjac, V., Petrović, J., Jovanović, P., Vulić, J., \& Zarić, D. (2018). Enrichment of dark chocolate with blackberry juice encapsulate: Impact on physical properties, sensory characteristics and polyphenol content. Lebensmittel-Wissenschaft + Technologie, 92, 458-464. http://dx.doi.org/10.1016/j.Iwt.2018.03.002

Muhoza, B., Xia, S., Cai, J., Zhang, X., Duhoranimana, E., \& Su, J. (2019). Gelatin and pectin complex coacervates as carriers for cinnamaldehyde: Effect of pectin esterification degree on coacervate formation, and enhanced thermal stability. Food Hydrocolloids, 87, 712-722. http://dx.doi.org/10.1016/j.foodhyd.2018.08.051

Namanga, J., Foba, J., Ndinteh, D. T., Yufanyi, D. M., \& Krause, R. W. M. (2013). Synthesis and magnetic properties of a superparamagnetic nanocomposite "pectin-magnetite nanocomposite. Journal of Nanomaterials, 2013, 1-8. http://dx.doi.org/10.1155/2013/137275

Outuki, P. M., Francisco, L. M. B., Hoscheid, J., Bonifácio, K. L., Barbosa, D. S., \& Cardoso, M. L. C. (2016). Development of arabic and xanthan gum microparticles loaded withan extract of Eschweilera nana Miers leaves with antioxidant capacity. Colloids and Surfaces A: Physicochemical and Engineering Aspects, 499, 103-112. http://dx.doi.org/10.1016/j.colsurfa.2016.04.006 
Ozkan, G., Franco, P., De Marco, I., Xiao, J., \& Capanoglu, E. (2019). A review of microencapsulation methods for food antioxidants: Principles, advantages, drawbacks and applications. Food Chemistry, 272, 494-506. PMid:30309574. http://dx.doi.org/10.1016/j.foodchem.2018.07.205

Pajin, B., Dokić, Lj., Zarić, D., Šoronja-Simović, D., Lončarević, I., \& Nikolić, I. (2013). Crystallization and rheological properties of soya milk chocolate produced in a ball mill. Journal of Food Engineering, 114(1), 70-74.

http://dx.doi.org/10.1016/j.jfoodeng.2012.06.024

Pradini, D., Juwono, H., Madurani, K. A., \& Kurniawan, F. (2018). A preliminary study of identification halal gelatin using quartz crystal microbalance (QCM) sensor. Malaysian Journal of Fundamental and Applied Sciences, 14(3), 325-330. http://dx.doi.org/10.11113/mjfas.v14n3.942

Ramos, S., Martín, M., \& Goya, L. (2017). Effects of cocoa antioxidants in type 2 diabetes mellitus. Antioxidants, 6(4), 84-100. PMid:29088075. http://dx.doi.org/10.3390/antiox6040084

Rutz, J. K., Borges, C. D., Zambiazi, R. C., Crizel-Cardozo, M. M., Kuck, L. S., \& Noreña, C. P. Z. (2017). Microencapsulation of palm oil by complex coacervation for application in food systems. Food Chemistry, 220, 59-66. PMid:27855936. http://dx.doi.org/10.1016/j.foodchem.2016.09.194

Sim, S. Y., Ng, J. W., Ng, W. K., Forde, C. G., \& Henry, C. J. (2016). Plant polyphenols to enhance the nutritional and sensory properties of chocolates. Food Chemistry, 200, 46-54. http://dx.doi.org/10.1016/j.foodchem.2015.12.092

Shah, A. S., Jones, G. P., \& Vasiljevic, T. (2010). Sucrose-free chocolate sweetened with Stevia rebaudiana extract and containing different bulking agents' effects on physicochemical and sensory properties. International Journal of Food Science \& Technology, 45(7), 1426-1435. http://dx.doi.org/10.1111/j.1365-2621.2010.02283.x

Silva Medeiros, N., Koslowsky Marder, R., Farias Wohlenberg, M., Funchal, C., \& Dani, C. (2015). Total phenolic content and antioxidant activity of different types of chocolate, milk, semisweet, dark, and soy, in cerebral cortex, hippocampus, and cerebellum of wistar rats. Biochemistry Research International, 2015, 294659. PMid:26649198. http://dx.doi.org/10.1155/2015/294659

Son, Y.-J., Choi, S.-Y., Yoo, K.-M., Lee, K.-W., Lee, S.-M., Hwang, I.-K., \& Kim, S. (2018). Anti-blooming effect of maltitol and tagatose as sugar substitutes for chocolate making. Lebensmittel-Wissenschaft + Technologie, 88, 87-94.

http://dx.doi.org/10.1016/j.Iwt.2017.09.018

Suarez-Quiroz, M. L., Alonso Campos, A., Valerio Alfaro, G., Gonzalez-Rıs, O., Villeneuve, P., \& Figueroa-Espinoza, M. C (2014). Isolation of green coffee chlorogenic acids using activated carbon. Journal of Food Composition and Analysis, 33(1), 5558. http://dx.doi.org/10.1016/j.jfca.2013.10.005

Toker, O. S., Konar, N., Palabiyik, I., Rasouli Pirouzian, H., Oba, S., Polat, D. G., Poyrazoglu, E. S., \& Sagdic, O. (2018). Formulation of dark chocolate as a carrier to deliver eicosapentaenoic and docosahexaenoic acids: Effects on product quality. Food Chemistry, 254, 224-231. PMid:29548446. http://dx.doi.org/10.1016/j.foodchem.2018.02.019

Wu, B., \& McClements, D. J. (2015). Functional hydrogel microspheres: Parameters affecting electrostatic assembly of biopolymer particles fabricated from gelatin and pectin. Food Research International, 72, 231-240. http://dx.doi.org/10.1016/j.foodres.2015.02.028

Xu, A. Y., Melton, L. D., Ryan, T. M., Mata, J. P., Jameson, G. B., Rekas, A., Williams, M. A., \& McGillivray, D. J. (2017). Sugarcoated proteins: The importance of degree of polymerisation of oligo-galacturonic acid on protein binding and aggregation. Soft Matter, 13(14), 2698-2707. PMid:28337496. http://dx.doi.org/10.1039/C6SM02660E

Yashin, A., Yashin, Y., Wang, J. Y., \& Nemzer, B. (2013). Antioxidant and antiradical activity of coffee. Antioxidants, 2(4), 230245. PMid:26784461. http://dx.doi.org/10.3390/antiox2040230 